\title{
Changes in fish species composition in the middle and lower Tietê River (Sáo Paulo, Brazil) throughout the centuries, emphasizing rheophilic and introduced species
}

\author{
Mudanças na composição de espécies no médio e baixo Rio Tietê (São Paulo, Brasil) \\ através dos séculos, enfatizando espécies reofílicas e introduzidas
}

Welber Senteio Smith ${ }^{1,2}$, Marta Severino Stefani2* ${ }^{2 *}$ Evaldo Luiz Gaeta Espíndola ${ }^{2}$

and Odete Rocha ${ }^{3}$

${ }^{1}$ Laboratório de Ecologia Estrutural e Funcional de Ecossistemas, Universidade Paulista - UNIP,

Av. Independência, 752, Iporanga, CEP 18103-000, Sorocaba, SP, Brasil

${ }^{2}$ Programa de Pós-graduaçáo em Ciências da Engenharia Ambiental, Centro de Recursos Hídricos

e Estudos Ambientais - CRHEA, Universidade de São Paulo - USP, Rodovia Domingos

Innocentini, Km 13, CEP 13560-970, Itirapina, SP, Brasil

${ }^{3}$ Departamento de Ecologia e Biologia Evolutiva - DEBE, Universidade Federal de São Carlos -

UFSCar, Rodovia Washington Luis, Km 235, CEP 13565-905, São Carlos SP, Brasil

*e-mail: ma_stefani@hotmail.com

Cite as: Smith, W.S. et al. Changes in fish species composition in the middle and lower Tietê River (São Paulo, Brazil) throughout the centuries, emphasizing rheophilic and introduced species. Acta Limnologica Brasiliensia, 2018, vol. 30, e310.

\begin{abstract}
Aim: This paper is aimed at describing the changes of fish species in the middle and lower courses of the Tietê River, emphasizing rheophilic and invasive fish species as well as identifying the causes for such alterations. Methods: Data collection consisted in: intense revision of publications, dissertations and thesis regarding the subject; information at the Zoology Museum at USP (MZUSP); revision in species identification through MUZUSP collection; historical survey of introduced species based on the literature and samplings in the years of 2000 and 2001. Results: The main impacts identified in the Tietê River with consequence to the ichthyofauna were: domestic and industrial pollution, deforestation, damming, course rectification, silting and species introduction. From the 80 species identified in the study area, 28 were invasive. Many fish species have been introduced in the Tietê River since the late 19th Century with carpa (Cyprinus carpio) being the first one, followed by the introduction of black bass (Mycropterus salmonoides) at the beginning of 20th Century. Other species such as corvina (Plagioscion squamosissimus) have been introduced by electricity companies, which has contributed to the species composition changes. Migratory species as dourado (Salminus brasiliensis), pacú (Piaractus mesopotamicus) and pintado (Pseudoplatystoma corruscans), which used to be abundant have become rare or absent after the construction of reservoirs, mainly because reservoirs in cascade have been built. Piracanjuba (Brycon orbignyanus), typically herbivore species, had its stock decreased due to the lack of ciliary vegetation and damming. Conclusions: Following the building of the reservoirs there have been important alterations in the composition of ichthyofauna, leading to the nearly complete absence of migratory species and the prevalent species are the ones which adapted to the new conditions. In addition to the damming, lack of ciliary vegetation and pollution also caused alterations in the ichthyological community.
\end{abstract}

Keywords: ichthyofauna; reservoir; environmental impacts; migratory species; invasive species. 
Resumo: Objetivo: Este trabalho descreve e busca identificar as causas de alteraçôes na composição de espécies de peixes no Médio e Baixo rio Tietê, com ênfase nas espécies reofílicas e invasoras. Métodos: Os dados foram obtidos através de uma intensa revisão de publicaçôes, dissertaçóes e teses realizadas na área de estudo, levantamento junto ao Museu de Zoologia da USP (MUZUSP), revisão na identificação das espécies através da coleção do MUZUSP, levantamento histórico de espécies introduzidas e espécies coletadas nos anos de 2000 e 2001. Resultados: Os principais impactos identificados no rio Tietê com consequências para a ictiofauna foram: poluição doméstica, poluição industrial, desmatamento, represamentos, retificação do leito, assoreamento e introdução de espécies. Das 80 espécies de peixes identificadas na área de estudo, 28 são invasoras. Diversas espécies de peixes têm sido introduzidas no rio Tietê desde o final do século XIX, sendo a primeira a carpa comum (Cyprinus carpio), seguida pela introduçáo do black bass (Mycropterus salmoides) no começo do século XX. Outras espécies como a corvina (Plagioscion squamosissimus) foram introduzidas por empresas do setor elétrico, o que contribuiu com a alteração da composição de espécies. As espécies migradoras como o dourado (Salminus brasiliensis), pacu (Piaractus mesopotamicus) e pintado (Pseudoplatystoma corruscans) que antes eram abundantes se tornaram raras ou ausentes após a construção dos reservatórios, principalmente por se tratarem de reservatórios em cascata. A piracanjuba (Brycon orbignyanus), espécie tipicamente herbívora, teve seu estoque reduzido devido à falta de vegetaçấo ciliar e os represamentos. Conclusóes: Após a construçáo dos reservatórios ocorreram profundas alteraçôes na composição da ictiofauna, sendo que espécies migradoras se tornaram praticamente ausentes e as espécies que predominam são as mais adaptadas às novas condiçóes. Além do represamento, a perda da mata ciliar e a poluição também causaram alteraçôes na comunidade íctica.

Palavras-chave: ictiofauna; reservatório; impactos ambientais; espécies migradoras; espécies invasoras.

\section{Introduction}

The reservoirs consist in important artificial ecosystems that alter the hydrological and ecological characteristics of a river (Tundisi, 1993), being regulated by the following factors: morphometry, seasoning, operation system, flow rate and residence time. Such factors not only alter the physical and chemical characteristics of the water (Straškraba $\&$ Tundisi, 2000; Smith et al., 2014) but also shape the structure of the fish communities (Pelicice et al., 2015). The reservoirs are the dominant environment in the Paraná River Basin and the fish shoals inhabiting these places have been altered from the original ones (Agostinho et al., 1995).

The creation of a new ecosystem, which becomes lentic, somehow constitutes another impact over the remaining communities in the upstream of the damming. This community will suffer modifications such as the reduction of some rheofilic species, which will be replaced by lentic adaptable species, for instance, the Curimatidae (Castro \& Arcifa, 1987; Smith \& Petrere Júnior, 2001; Agostinho et al., 2008).

In reservoirs there is a change in the composition and structure of fish assembly, leading to a high increase of some species and decrease and even extinction of others. The impact level over the biological diversity is linked to the characteristics of the local fauna, damming location, patterns of circulation, depth and area of the artificial lake, the existence of other dams upstream and the operational procedures of the reservoir (Agostinho et al., 1995).

Furthermore, the impact over the fish community will depend on several factors, such as the type and size of the river, of great importance, the location and maintenance of vegetal coverage in the margins, the presence of tributaries used for the rheophilic reproduction and the effect of the reservoirs in cascade. Many rheophilic species may survive in the reservoir using the tributaries for reproduction (Smith et al., 2014).

Besides the impacts caused by the construction of reservoirs and their operation, the fish community is subject to several impacts which contribute heavily to the loss of species, as well as the decrease of riparian vegetation, pollution and the introduction of species, which may lead to the reduction of its biomass and abundance and consequently its complete extinction (Smith et al., 2002; Vitule et al., 2009).

There are some studies regarding the composition of the ichthyofauna concerning the Middle and Lower Tietê River. Some examples, Monteiro (1953) evaluated the contribution to the fishery study in the Piracibaba River, and Rocha et al. (2011) described animal invaders in São Paulo state reservoirs. The impacts of the reservoirs and its gradients of middle and lower Tietê, fishing modification due to dam, pollution and the introduction of fish species (Smith et al., 2002, 2003a, 2014; Moretto et al., 2008), and large reservoirs as ecological barriers 
to downstream movements were also studied (Pelicice et al., 2015).

Considering all the impact here presented, this paper describes the alterations in the composition of fish species along years, through a historical survey of species introduction and several changes as well as presenting the impacts suffered by the Tietê River in addition to the existing dams.

\section{Material and Methods}

The area chosen for the study is in the middle and lower courses of the Tietê River (Figure 1). This river is one of the most important water bodies of São Paulo State, crossing from the Serra do Mar mountain chain to the Paraná River. Its total length is $1,150 \mathrm{Km}$ and the great unevenness of its course was used for the construction of dams to produce electricity. Currently it is a navigable river from the Jupiá Dam in the Paraná River $(40 \mathrm{Km})$, and the stretches between the dams of Barra Bonita and Nova Avanhandava (443 Km) (Smith et al., 2003a).

The data presented in this paper were obtained through revision of publications, dissertations and thesis accomplished between 1953 and 2015, in the study area as well as a survey conducted at the Zoology Museum at USP, Section of Fishes, aiming at evaluating all the species which have already been collected in the study area and possibly deposited. The referred literature was chosen according to the presence of the following key words: Tietê river, damming, fish ecology, fish diversity, dam impacts, fish management, fish conservation, fish introduction, fish community, native species, cascading reservoirs, fishway, fish migration. Was used the databases ISI Web of Knowledge, Google Scholar and Scopus.

Moreover, a revision of the species identification was made in the literature found. Such revision was based on papers done in the study area, intending to rectify or update the species identification made by other authors and having a more reliable and complete list of species occurring in the study area. Another important point raised was related to the introduced species, whose survey made it possible to identify the invasive species with greater accuracy, their original occurrence and how they have been introduced.

In order to complete the data we performed samplings in January 2000 (rainy season), January 2001 (rainy season) and in July 2001 (dry season). The samplings were made along the middle and lower courses of the Tietê River with two sets of fishing nets containing 8 nets with different mesh sizes $(3,4,5,6,7,8,10$ and $12 \mathrm{~cm}$, between opposed knots), dip net and dragging nets. The sets were put in the reservoir and tributaries edge area in different depths (surface half-water and half water-deep). Besides, dip nets were used to collect fish with macrophyte and vegetation also located in the edge area and dragging net in river beaches or places allowing their passage.

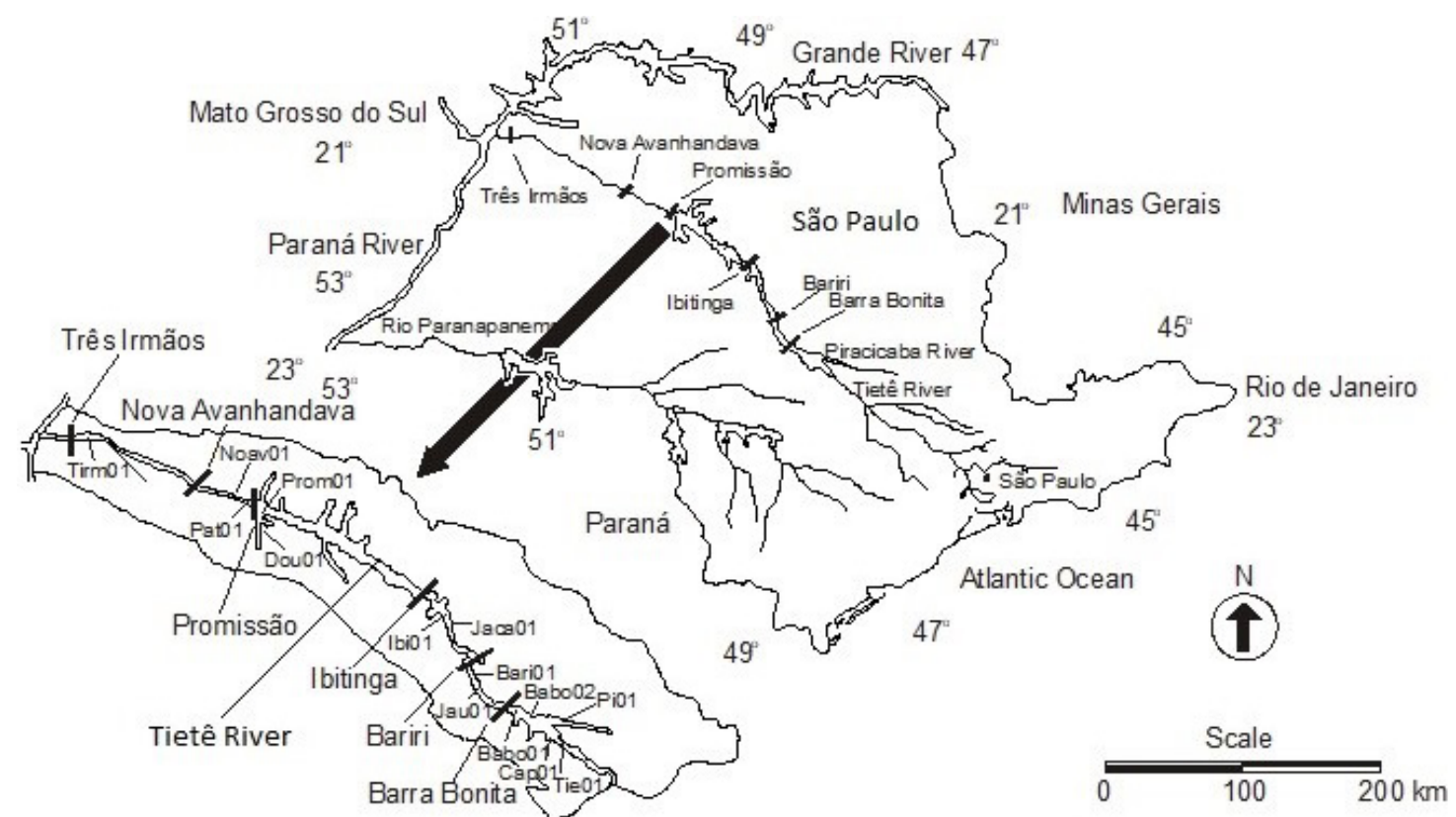

Figure 1. Location of the reservoirs, main tributaries and distribution of the sampling stations in the Tietê River, SP. 
The fishes which were captured were fixed in formaline $10 \%$ and conserved in alcohol $70 \%$, being stored in plastic recipients and transported to the Núcleo de Estudos de Ecossistemas Aquaticos (NEEA), of the the Centro de Recursos Hídricos e Estudos Ambientais (CRHEA), of the Departamento de Hidráulica e Saneamento (SHS), in the Escola de Engenharia de São Carlos (EESC), Universidade de São Paulo (USP) in São Carlos, São Paulo State, where they were identified using identification keys (Britski, 1972; Britski et al., 1984; Garutti \& Britski, 2000). Afterwards, species were confirmed in comparison to the material deposited at the Museum of Zoology at USP, Fish Section.

\section{Results}

The modifications in the Tietê River and its ichthyofauna of throughout the years occurred due to domestic and industrial pollution, deforestation, damming, course rectification, silting and species introduction (Table 1 and Table 2). In the 17 th Century, the ciliary forest had already been damaged in the upper course of the Tietê River and more recently the dammings in the middle and lower courses of the Tietê River have strengthened the modification in the composition of fish species. Such impacts caused a series of modifications in the fish population and communities, leading to severe alterations in the composition of species along the Tietê River, as dominance of exotic species and the presence of species that did not occurs previously.

By using data presented in Machado et al. (1968), CNEC (1969) and Nóbrega (1978), it was possible to verify that in the 17 th, 18 th and 19 th Centuries migratory species were common, in addition to the more commonly found species today (Table 3). From the 19th Century on, migratory species became less abundant in the stretch crossing Sáo Paulo City, causing a simplification of the ichthyofauna.

In the first half of the 20th Century, it was still possible to find migratory species as dourado (Salminus brasiliensis), pacú (Piaractus mesopotamicus), pintado (Pseudoplatystoma corruscans) and piracanjuba (Brycon orbynianus) in the stretches of the middle and lower course of the Tietê River, before the constructions of the reservoirs. From the sixties on, because of dams in cascade, such species began to occur in reduced number resulting in the almost complete absence from the eighties on. Nonetheless, curimbatá (Prochilodus lineatus) and tabarana (Salminus hilarii) may still be found in the Tietê River.

Information regarding before the building of the dams is scarce and it may be found in a few papers such as Monteiro's from 1953 about the Piracicaba River but it mentions the Tietê River as far as Barra Bonita reservoir. There are also other studies which date back to the sixties, when the abundance of migratory species such as dourado (Salminus brasiliensis), pintado (Pseudoplatystoma corruscans), jaú (Zungaro jahu) e piracanjuba (Brycon orbygnianus) was reported in fishing. Such species became rare after the dammings and recurrent impacts being suffered by the Tietê River. In the Tietê River, from the 80 species which were identified 28 have been introduced (Table 4).

The first introductions in the Tietê River data back to the end of the 19th Century. The first species to be introduced was the carpa (Cyprinus carpio). Afterwards, there was the introduction of black bass (Mycropterus salmoides), around 1909 in several dams, including the Ponta Nova dam in the upper course of the Tietê River. Imported from Congo,

Table 1. Main impacts in the middle and lower courses of the Tietê River and their consequences to the river.

\begin{tabular}{ll}
\hline \multicolumn{1}{c}{ Impact } & \multicolumn{1}{c}{ Consequence on the environment } \\
\hline $\begin{array}{l}\text { Domestic pollution } \\
\text { Industrial Pollution } \\
\text { Deforestation }\end{array}$ & $\begin{array}{l}\text { Alteration in water physical and chemical characteristics, nutrient cycling; eutrophycation } \\
\text { Alteration in water physical and chemical characteristics. } \\
\text { Erosion, temperature change, and incidence of light, decrease in the environment stability, } \\
\text { silting, simplification of aquatic habitats, alteration in the river bed. }\end{array}$ \\
$\begin{array}{l}\text { Dammings } \\
\text { Alteration in water physical and chemical characteristics. } \\
\text { Silt removal }\end{array}$ & Habitat destruction. \\
Introduction of species & Habitat destruction
\end{tabular}

Based on information from: Moring et al. (1985), Hassel et al. (1998), Beaumord \& Petrere Júnior (1994), Barrella et al. (1994, 2000), Johnson et al. (1995), FAO (1997), Stauffer et al. (2000), Matthews (1998), Smith (1999), Smith et al. (2002, 2003a, b) and Barrella \& Petrere Júnior (2003). 
Table 2. Main impacts in the middle and lower courses of the Tietê River and their consequences to the ichthyofauna.

\begin{tabular}{|c|c|c|}
\hline Impacts & Consequence to the fishes & $\begin{array}{l}\text { Consequence to the populations and } \\
\text { communities }\end{array}$ \\
\hline $\begin{array}{l}\text { Domestic } \\
\text { Pollution }\end{array}$ & $\begin{array}{l}\text { Alteration in the enzymatic activities (causing } \\
\text { stress), in activities (swimming), feeding, mucus } \\
\text { production and death. }\end{array}$ & $\begin{array}{l}\text { Increase in eggs, young and adult fish death, } \\
\text { reduction of abundance, richness and diversity; } \\
\text { interference in the distribution of abundance and } \\
\text { decrease in the community's complexity. }\end{array}$ \\
\hline $\begin{array}{l}\text { Industrial } \\
\text { Pollution }\end{array}$ & $\begin{array}{l}\text { Alteration in the enzymatic activities (causing } \\
\text { stress), in the activities (swimming) feeding, } \\
\text { mucus production and death. }\end{array}$ & $\begin{array}{l}\text { Increase in eggs, fingerlings and adult fish death, } \\
\text { reduction of abundance, richness and diversity; } \\
\text { interference in the distribution of abundance and } \\
\text { decrease in the community complexity. }\end{array}$ \\
\hline Deforestation & $\begin{array}{l}\text { Decrease in feeding resources, shelters and } \\
\text { reproduction. }\end{array}$ & $\begin{array}{l}\text { Reduction of abundance, richness and diversity, } \\
\text { interference in the distribution of abundance, and } \\
\text { decrease in the complexity of the community. }\end{array}$ \\
\hline Siltings & $\begin{array}{l}\text { Decrease in feeding resources, shelters and } \\
\text { reproduction. }\end{array}$ & Damage in eggs and fingerlings' development. \\
\hline Dammings & $\begin{array}{l}\text { Interference in the migratory species } \\
\text { reproduction. }\end{array}$ & $\begin{array}{l}\text { Increase of predation, reduction of abundance, } \\
\text { richness and diversity of species, interference in } \\
\text { the distribution of abundance and decrease in the } \\
\text { community's complexity. }\end{array}$ \\
\hline $\begin{array}{l}\text { Course } \\
\text { Rectification }\end{array}$ & $\begin{array}{l}\text { Decrease in feeding resources, shelters and } \\
\text { reproduction. }\end{array}$ & Increase in the eggs and juveniles' death. \\
\hline Silt removal & $\begin{array}{l}\text { Decrease in feeding resources, shelters and } \\
\text { reproduction. }\end{array}$ & Increase in the eggs and juveniles' death. \\
\hline $\begin{array}{l}\text { Introduction of } \\
\text { species }\end{array}$ & $\begin{array}{l}\text { Transmission of diseases and parasites, } \\
\text { competition and predation. }\end{array}$ & $\begin{array}{l}\text { Reduction of abundance, richness and diversity, } \\
\text { interference in the distribution of abundance, and } \\
\text { decrease in the complexity of the community. }\end{array}$ \\
\hline
\end{tabular}

Based on information from: Moring et al. (1985), Hassel et al. (1998), Beaumord \& Petrere Júnior (1994), Barrella et al. (1994, 2000), Johnson et al. (1995), FAO (1997), Stauffer et al. (2000), Matthews (1998), Smith (1999), Smith et al. (2002, 2003a, b), Barrella \& Petrere Júnior (2003), Agostinho et al. (2008, 2016), Rocha et al. (2011) and Pelicice et al. (2015).

tilápias were introduced in São Paulo State in 1952 by São Paulo Light, aiming at populating the dam on the upper part of the Serra do Mar mountain chain. The corvina (Plagioscion squamosissimus) was introduced in São Paulo state in 1966 by CESP, in the Pardo River, reaching the Grande River and Paraná River and in Ilha Solteira and Jupiá reservoirs, occupying Tietê River (Braga, 1998; Agostinho \& Julio Júnior, 1996, 1999; Smith et al., 2003a). Then, tucunaré (Cichla kelberi), sardinha (Triportheus nematurus), trairão (Hoplias lacerdae) and tambaqui (Colossoma macropomum), among others. There is no accurate data to be properly informed.

\section{Discussion}

The main modifications over time in the middle and lower courses of the Tietê River were the reduction of migratory species and the introduction of species. Although there was a change in the fish community, the number of species remained stable throughout the studied period. The dams in the Tietê River prevent the migration of some species, such as jaú (Zungaro jahu), pintado (Pseudoplatystoma corruscans) and dourado (Salminus maxillosus), among others. These species cannot go upstream and migrate to areas where they can reproduce. Smith et al. (2002), shows a reduction of migratory species caught professionally in the area where Barra Bonita Reservoir is situated. According to Monteiro, in 1953, prior to the dam constructions, a great amount of curimbatá (Prochilodus lineatus), dourado (Salminus brasiliensis), jaú (Zungaro jahu) and pintado (Pseudoplatystoma corruscans) was caught. In 1989, after the building of the dams, such amount dropped drastically and many of these species disappeared from this river. Agostinho et al. (1999) also noted alterations in the fish catching from 1977 to 1997 in the Paraná River, showing that before the dam constructions, most species present there were migratory, such as Zungaro jahu, Salminus brasiliensis and Prochilodus lineatus and after the damming non-migratory and invasive species as Pterodoras granulosus (Valenciennes, 1821), Plagioscion squamosissimus and Hypophthalmus edentatus were prevailing.

The change in fish community seems to be the main characteristic of damming regions. 
Table 3. Main fish species captured by fishing (amateur, sports and experimental) in the Tietê River, SP, Brazil, from the 17th Century to the current days.

\begin{tabular}{|c|c|c|c|c|c|}
\hline \multirow[b]{2}{*}{ Species } & \multirow[b]{2}{*}{$\begin{array}{l}\text { Common } \\
\text { name }\end{array}$} & \multicolumn{4}{|c|}{ Period } \\
\hline & & $\begin{array}{c}\text { 17th and } \\
\text { 18th Centuries }\end{array}$ & $\begin{array}{l}\text { 19th } \\
\text { Century }\end{array}$ & $\begin{array}{l}\text { 20th Century } \\
\text { (first half) }\end{array}$ & $\begin{array}{l}\text { 20th Century } \\
\text { (second half) }\end{array}$ \\
\hline Zungaro jahu (Ihering, 1898) & Jaú & $\mathrm{x}$ & $\mathrm{x}$ & $\mathrm{x}$ & \\
\hline $\begin{array}{l}\text { Pseudoplatystoma corruscans (Spix \& } \\
\text { Agassiz, 1829) }\end{array}$ & Pintado & $x$ & $x$ & $x$ & \\
\hline Salminus brasiliensis (Cuvier, 1816) & Dourado & $\mathrm{x}$ & $\mathrm{x}$ & $\mathrm{x}$ & \\
\hline Salminus hilarii Valenciennes, 1850 & Tabarana & $\mathrm{x}$ & $\mathrm{x}$ & $\mathrm{x}$ & $\mathrm{x}$ \\
\hline $\begin{array}{l}\text { Piaractus mesopotamicus (Holmberg, } \\
\text { 1887) }\end{array}$ & Pacú & $x$ & $x$ & $x$ & \\
\hline $\begin{array}{l}\text { Brycon orbignyanus (Valenciennes in } \\
\text { Cuvier \& Valenciennes, 1850) }\end{array}$ & Piracanjuba & $x$ & $x$ & $x$ & \\
\hline $\begin{array}{l}\text { Hemisorubim platyrhynchos } \\
\text { (Valenciennes, 1840) }\end{array}$ & Jurupoca & $x$ & $x$ & $x$ & \\
\hline $\begin{array}{l}\text { Prochilodus lineatus (Valenciennes, } \\
\text { 1836) }\end{array}$ & Curimbatá & $x$ & $x$ & $x$ & $x$ \\
\hline Schizodon sp. & Ximborê & $\mathrm{x}$ & $\mathrm{x}$ & $\mathrm{x}$ & $\mathrm{x}$ \\
\hline Astyanax sp. (several species) & Lambari & $\mathrm{x}$ & $\mathrm{x}$ & $\mathrm{x}$ & $\mathrm{x}$ \\
\hline Leporinus sp. (several espécies) & Piava & $x$ & $x$ & $x$ & $x$ \\
\hline $\begin{array}{l}\text { Myleus tietê (Eigenmann \& Norris, } \\
\text { 1900) }\end{array}$ & Pacupeba & $x$ & $x$ & $x$ & \\
\hline $\begin{array}{l}\text { Rhamdia quelen (Quoy \& Gaimard, } \\
\text { 1824) }\end{array}$ & Bagre & $x$ & $x$ & $x$ & $x$ \\
\hline $\begin{array}{l}\text { Pimelodus maculatus La Cepède, } \\
1803\end{array}$ & Mandi & $x$ & $x$ & $x$ & $x$ \\
\hline Hoplias malabaricus (Bloch, 1794) & Traíra & $\mathrm{x}$ & $\mathrm{x}$ & $\mathrm{x}$ & $\mathrm{x}$ \\
\hline $\begin{array}{l}\text { Cyphocharax modestus (Fernández- } \\
\text { Yépez, 1948) }\end{array}$ & Saguiru & $x$ & $x$ & $\mathrm{x}$ & $x$ \\
\hline $\begin{array}{l}\text { Steindachnerina insculpta (Fernández- } \\
\text { Yépez, 1948) }\end{array}$ & Saguiru & $\mathrm{x}$ & $x$ & $\mathrm{x}$ & $x$ \\
\hline $\begin{array}{l}\text { Geophagus brasiliensis (Quoy \& } \\
\text { Gaimard, 1824) }\end{array}$ & Cará & $x$ & $x$ & $x$ & $x$ \\
\hline Serrasalmus maculatus Kner, 1858 & Pirambeba & & & $\mathrm{x}$ & $x$ \\
\hline $\begin{array}{l}\text { Plagioscion squamosissimus (Heckel, } \\
\text { 1840) }\end{array}$ & Corvina & & & & $x$ \\
\hline $\begin{array}{l}\text { Moenkhausia intermedia Eigenmann, } \\
1908\end{array}$ & $\begin{array}{l}\text { Lambari- } \\
\text { corinthiano }\end{array}$ & & & & $x$ \\
\hline $\begin{array}{l}\text { Cichla kelberi Kullander \& Ferreira, } \\
2006\end{array}$ & Tucunaré & & & & $x$ \\
\hline Metynnis maculatus (Kner, 1858) & Pacu-prata & & & & $\mathrm{x}$ \\
\hline $\begin{array}{l}\text { Satanoperca pappaterra (Heckel, } \\
1840)\end{array}$ & Cará & & & & $x$ \\
\hline Coptodon rendalli (Boulenger, 1897) & Tilápia & $\mathrm{x}$ & $\mathrm{x}$ & $\mathrm{x}$ & $\mathrm{x}$ \\
\hline Number of species & & 19 & 19 & 20 & 18 \\
\hline
\end{tabular}

Based on information from Monteiro (1953) and Smith et al. (2002, 2003a).

As also observed in the Paraná River by Agostinho et al. (1999), migratory species were abundant in the Tietê River before the damming. Currently non-migratory and introduced species are prevalent. Besides, fishermen emphasize that fish such as dourado and pintado are rarely captured and composition of species in fishing has changed greatly over the last years due to the damming and the introduction of exotic and alien species, increasing the capture of introduced species, wild species and small-sized species instead of large-sized species which have higher price (Smith, 2006).

The loss of riparian vegetation contributed to the alteration of the species composition, decreasing the piracanjuba population (Brycon orbygnianus), since those are typically herbivore. Such loss also resulted in the almost complete disappearance of other species, such as pacú (Piaractus mesopotamicus) and pacuzinho (Myleus tiete). Along with those impacts it is important to highlight the introduction of species in the Tietê River. 
Table 4. Species of fish introduced in the middle and lower courses of the Tietê River, SP, Brazil.

\begin{tabular}{|c|c|c|c|c|}
\hline Common Name & Species & Origin & $\begin{array}{c}\text { Introduction } \\
\text { Year }\end{array}$ & Introduction Place \\
\hline Black bass & $\begin{array}{l}\text { Micropterus salmoides (La } \\
\text { Cepède, 1802) }\end{array}$ & North America & 1909 & Ponte Nova Damming \\
\hline Carpa & $\begin{array}{l}\text { Cyprinus carpio Linnaeus, } \\
1758\end{array}$ & Asia & About 1939 & $\begin{array}{l}\text { Many rivers in São Paulo } \\
\text { state }\end{array}$ \\
\hline Tilápia & $\begin{array}{l}\text { Coptodon rendalli } \\
\text { (Boulenger, 1897) }\end{array}$ & Africa & 1952 & $\begin{array}{l}\text { Dams on the upper part of } \\
\text { the Serra do Mar mountain } \\
\text { chain }\end{array}$ \\
\hline Tilápia & $\begin{array}{l}\text { Oreochromis niloticus } \\
\text { (Linnaeus, 1758) }\end{array}$ & Africa & After 1952 & * \\
\hline Apaiari & $\begin{array}{l}\text { Astronotus crassipinnis } \\
\text { (Heckel, 1840) }\end{array}$ & Africa & After 1952 & * \\
\hline Apaiari & $\begin{array}{l}\text { Astronotus ocellatus } \\
\text { (Agassiz, 1831) }\end{array}$ & Amazon & After 1938 & * \\
\hline Corvina & $\begin{array}{l}\text { Plagioscion } \\
\text { squamosissimus (Heckel, } \\
\text { 1840) }\end{array}$ & Amazon & From 1966 on & $\begin{array}{l}\text { From the Itapura on (river } \\
\text { mouth) }\end{array}$ \\
\hline Tucunaré & $\begin{array}{l}\text { Cichla kelberi. Kullander \& } \\
\text { Ferreira, } 2006\end{array}$ & Amazon & $\begin{array}{l}\text { From the eighties } \\
\text { on }\end{array}$ & $\begin{array}{l}\text { Reservoirs in the middle and } \\
\text { lower courses of Tietê River }\end{array}$ \\
\hline $\begin{array}{l}\text { Sardinha de } \\
\text { água-doce }\end{array}$ & $\begin{array}{l}\text { Triportheus nematurus } \\
\text { (Kner, 1858) }\end{array}$ & Northeast of Brazil & $\begin{array}{l}\text { From the eighties } \\
\text { on }\end{array}$ & $\begin{array}{l}\text { Reservoirs in the middle and } \\
\text { lower courses of Tietê River }\end{array}$ \\
\hline Cará & $\begin{array}{l}\text { Satanoperca pappaterra } \\
\text { (Heckel, 1840) }\end{array}$ & Amazon & $\begin{array}{l}\text { From the eighties } \\
\text { on }\end{array}$ & $\begin{array}{l}\text { From the Itapura on (river } \\
\text { mouth) }\end{array}$ \\
\hline Cará & $\begin{array}{l}\text { Geophagus surinamensis } \\
\text { (Bloch, 1791) }\end{array}$ & Amazon & $\begin{array}{l}\text { From the eighties } \\
\text { on }\end{array}$ & $\begin{array}{l}\text { From the Itapura on (river } \\
\text { mouth) }\end{array}$ \\
\hline Pacú-prata & $\begin{array}{l}\text { Metynnis maculatus (Kner, } \\
\text { 1858) }\end{array}$ & * & $\begin{array}{l}\text { From the eighties } \\
\text { on }\end{array}$ & $\begin{array}{l}\text { From the Itapura on (river } \\
\text { mouth) }\end{array}$ \\
\hline Cascudo & $\begin{array}{l}\text { Pterygoplichthys anisitsi } \\
\text { Eigenmann \& Kennedy, } \\
1903\end{array}$ & * & $\begin{array}{l}\text { From the eighties } \\
\text { on }\end{array}$ & $\begin{array}{l}\text { From the Itapura on (river } \\
\text { mouth) }\end{array}$ \\
\hline Bagre & $\begin{array}{l}\text { Trachelyopterus coriaceus } \\
\text { Valenciennes, } 1840\end{array}$ & * & $\begin{array}{l}\text { From the eighties } \\
\text { on }\end{array}$ & $\begin{array}{l}\text { From the Itapura on (river } \\
\text { mouth) }\end{array}$ \\
\hline Barbado & $\begin{array}{l}\text { Pinirampus pirinampu } \\
\text { (Spix \& Agassiz, 1829) }\end{array}$ & $\begin{array}{l}\text { Paraná River lower } \\
\text { course }\end{array}$ & Itaipu Reservoir & $\begin{array}{l}\text { From the Itapura on (river } \\
\text { mouth) }\end{array}$ \\
\hline Lambari-bocarra & $\begin{array}{l}\text { Roeboides pananensis } \\
\text { Pignalberi, } 1975\end{array}$ & $\begin{array}{l}\text { Paraná River lower } \\
\text { course }\end{array}$ & Itaipu Reservoir & $\begin{array}{l}\text { From the Itapura on (river } \\
\text { mouth) }\end{array}$ \\
\hline Caborja & $\begin{array}{l}\text { Hoplosternum littorale } \\
\text { (Hancock, 1828) }\end{array}$ & Spread distribution & * & * \\
\hline Tambaqui & $\begin{array}{l}\text { Colossoma macropomum } \\
\text { (Cuvier, 1816) }\end{array}$ & Amazon & * & * \\
\hline Trairão & $\begin{array}{l}\text { Hoplias lacerdae Miranda } \\
\text { Ribeiro, } 1908\end{array}$ & $\begin{array}{l}\text { Paraná River } \\
\text { upper course }\end{array}$ & * & * \\
\hline Cará & $\begin{array}{l}\text { Geophagus proximus } \\
\text { (Castelnau, 1855) }\end{array}$ & Amazon & * & $\begin{array}{l}\text { Reservoirs in the middle and } \\
\text { lower courses of Tietê River }\end{array}$ \\
\hline Piauçu & $\begin{array}{l}\text { Leporinus macrocephalus } \\
\text { Garavello \& Britski, } 1988\end{array}$ & $\begin{array}{l}\text { Paraguai River } \\
\text { Basin (Probably) }\end{array}$ & * & $\begin{array}{l}\text { Reservoirs in the middle and } \\
\text { lower courses of Tietê River }\end{array}$ \\
\hline Pacu-prata & $\begin{array}{l}\text { Metynnis mola Eigenmann } \\
\text { \& Kennedy, } 1903\end{array}$ & $\begin{array}{l}\text { Paraguai River } \\
\text { Basin (Probably) }\end{array}$ & * & $\begin{array}{l}\text { Reservoirs in the middle and } \\
\text { lower courses of Tietê River }\end{array}$ \\
\hline Jeju & $\begin{array}{l}\text { Hoplerythrinus unitaeniatus } \\
\text { (Agassiz, 1829) }\end{array}$ & $\begin{array}{l}\text { Paraguai River } \\
\text { Basin (Probably) }\end{array}$ & * & $\begin{array}{l}\text { Reservoirs in the middle and } \\
\text { lower courses of Tietê River }\end{array}$ \\
\hline Cascudo-preto & $\begin{array}{l}\text { Rhinelepis aspera Spix e } \\
\text { Agassiz, } 1829\end{array}$ & $\begin{array}{l}\text { Paraguai River } \\
\text { Basin (Probably) }\end{array}$ & * & $\begin{array}{l}\text { Reservoirs in the middle and } \\
\text { lower courses of Tietê River }\end{array}$ \\
\hline Jurupecém & $\begin{array}{l}\text { Ageneiosus militaris } \\
\text { Valenciennes, } 1835\end{array}$ & Amazon (Probably) & * & $\begin{array}{l}\text { Reservoirs in the middle and } \\
\text { lower courses of Tietê River }\end{array}$ \\
\hline Tucunaré & $\begin{array}{l}\text { Cichla monoculus Spix \& } \\
\text { Agassiz, } 1831\end{array}$ & Amazon (Probably) & * & $\begin{array}{l}\text { Reservoirs in the middle and } \\
\text { lower courses of Tietê River }\end{array}$ \\
\hline Tucunaré & $\begin{array}{l}\text { Cichla temensis Humboldt, } \\
1821\end{array}$ & Amazon (Probably) & * & $\begin{array}{l}\text { Reservoirs in the middle and } \\
\text { lower courses of Tietê River }\end{array}$ \\
\hline Tilápia-branca & $\begin{array}{l}\text { Oreochromis mossambicus } \\
\text { (Peters, 1852) }\end{array}$ & Africa & * & $\begin{array}{l}\text { Reservoirs in the middle and } \\
\text { lower courses of Tietê River }\end{array}$ \\
\hline
\end{tabular}

Based on: Machado et al. (1968), CNEC (1969), Monteiro (1953), Smith et al. (2002, 2003a, b), Sazima (2007), Moretto et al. (2008) and Rocha et al. (2011); ${ }^{*}$ Unknown information. 
Agostinho et al. (1992) claimed that in reservoirs there is a change in the composition and structure of fish assembly, featuring excessive increase of some species and decrease or even extinction of others. The clearest response from the fish community in dams was not the disappearance of species but the modification in their structure. Such result is like the one obtained for the Tietê River where several migratory species disappeared. Besides the damming, the loss of species is the result of high deforestation and pollution rates (Smith et al., 2003a). In the Três Irmãos Reservoir it is difficult to catch lambaris, Astyanax lacustris Lütken, 1875, Astyanax fasciatus (Cuvier 1819) and cará (Geophagus brasiliensis), forage species which have nearly disappeared as a consequence of the construction of the reservoir and the pressure caused by the introduced species and the increase of population of other species such as pirambeba (Serrasalmus maculatus).

Some species are benefited by damming, as the small-sized ones with fractional spawning, non-migratory and able to use more abundant resources in the reservoirs, such as debris, higher plants, algae and fish. Examples of such species are saguirus (Cyphocharax modestus and Steindachnerina insculpta) and lambaris (Astyanax lacustris, Astyanax fasciatus) and Moenkhausia intermedia) which may be found in the upper course of the Paraná River Basin. These species complete their reproductive cycle in the reservoirs themselves or in their influence area. For these species, there was a increase of the abundance due to the modification in the ecosystem which was lotic and became lentic, making the conditions more favorable (Castro \& Arcifa, 1987).

The construction of reservoirs boosted especially the introduction of invasive species from 1960 on. Energy companies were responsible for introducing such species, aiming at improving fishing activity since several native species such as dourado (Salminus maxillosus), pintado (Pseudoplatystoma corruscans), jaú (Zungaro jahu) and piracanjuba (Brycon orbygnianus), had had their stocks reduced (Smith et al., 2002, 2003a). It is important to point out that the deforestation of ciliary forest and pollution has also contributed to this reality.

Another aspect to be discussed is that damming eliminates natural obstacles that prevented some fish species to move on to drainage (Pelicice et al., 2015). In Brazil, a typical case refers to the Sete Quedas Falls in the Paraná River. Those waterfalls were flooded by the Itaipu Reservoir and were no longer an obstacle to the aquatic fauna found in the lower course of the Paraná River. Thus, some species with restrict distribution began to occupy upstream areas following the building of the reservoirs.

In the past, the introduction of species was regarded as an interesting activity to increase commercial fishing. Today though, it is highly agreed that such practice is not advisable, and it may have contributed to the reduction and even disappearance of native species (Hilsdorf \& Petrere, 2002). The impacts brought about by exotic and alien species are little known in aquatic Brazilian ecosystems. Despite, information about possible signs of impact may already be found. The tucunaré, species from the Amazon, is considered a natural enemy to native species (Rocha et al., 2011) because it caused several species to end in a lake (Zaret \& Paine, 1973). Furthermore, tucunaré is "good for fishermen", but extremely damaging to the environment.

There are many negative examples imposed by the introduction of fish species. Amongst them are the loss of species, the reduction of the amount of fish caught and alteration in the environment due to the decrease of spawning areas and even eutrophication (Welcomme, 1988; Fernando, 1991; Ross, 1991; Agostinho \& Julio Júnior, 1996; Smith et al., 2003a). Such effect occurs especially when piscivore species are introduced pressuring native species either for predation or for competition. Besides, the introduced species may behave differently from what had been expected, occupying niches that are distinct from their regular ones.

Therefore, the damming in middle and lower courses of the Tietê River caused an important change in fish species composition, since many migratory species are no longer found in these stretches and the species which take advantage from the lentic environment are predominant. Besides all impacts caused by the damming and introduction of exotic species, the middle and lower courses of the Tietê River also suffer with different sources of pollution specially came from the São Paulo city, silting and lack of riparian vegetation. All of those factors contribute to changes in the composition of ichthyofauna throughout the years.

\section{Acknowledgements}

Thanks to Dr. Osvaldo Takeshi Oyakawa, Professor Dr. Heraldo A. Britski and Dr. Flavio César Thadeo de Lima for fish identification; Airton 
Soares Santos, Irieme Smith and Marcos César Rodrigues Senteio for field work; and São Paulo Research Foundation (FAPESP) for the first author scholarship (grant\#1999/12112-9).

\section{References}

AGOSTINHO, A.A. and JULIO JÚNIOR, H.F. Peixes de outras águas. Ciência Hoje, 1996, 21(124), 26-44.

AGOSTINHO, A.A. and JÚLIO JÚNIOR, H.F. Peixes da bacia do alto rio Paraná. In: R.H. LOWEMCCONNELL, ed. Estudos ecológicos de comunidades de peixes tropicais. São Paulo: EDUSP, 1999, pp. 374-400.

AGOSTINHO, A.A., GOMES, L.C., SANTOS, N.C., ORTEGA, J.C. and PELICICE, F.M. Fish assemblages in Neotropical reservoirs: colonization patterns, impacts and management. Fisheries Research, 2016, 173, 26-36. http://dx.doi.org/10.1016/j. fishres.2015.04.006

AGOSTINHO, A.A., JULIO JÚNIOR, H.F. and BORGHETTI, J.R. Consideraçóes sobre os impactos dos represamentos na ictiofauna e medidas para sua atenuação: um estudo de caso: reservatório de Itaipu. Revista UNIMAR, 1992, 14, 89-107.

AGOSTINHO, A.A., OKADA, E.K. and GREGORIS, J. A pesca no reservatório de Itaipu: aspectos sócioeconômicos e impactos de represamento. In: R. HENRY, ed. Ecologia de reservatórios: estrutura, função $e$ aspectos sociais. Botucatu: FUNDIBIO/FAPESP, 1999, pp. 279-320.

AGOSTINHO, A.A., PELICICE, F.M. and GOMES, L.C. Dams and the fish fauna of the Neotropical region: impacts and management related to diversity and fisheries. Brazilian Journal of Biology $=$ Revista Brasileira de Biologia, 2008, 68(4), 1119-1132, Supplement. PMid:19197482.

AgOSTINHO, A.A., VAZZOLER, A.E.A.M. and THOMAZ, S.M. The high River Paraná Basin: limnological and ichthyological aspects. In: J.G. TUNDISI, C.E.M. BICUDO and T. MATSUMURA-TUNDISI, eds. Limnology in Brazil. Rio de Janeiro, ABC/SBL, 1995, pp. 59-103.

BARRELLA, W. and PETRERE JÚNIOR, M. Fish community alterations due to pollution and damming In Tietê and Paranapanema Rivers (Brazil). River Research and Applications, 2003, 19(1), 5-76. http://dx.doi.org/10.1002/rra.697.

BARRELLA, W., BEAUMORD, A.C. and PETRERE JÚNIOR, M. Comparacion de la comunidad de peces de los rios Manso (MT) y Jacare Pepira River (SP), Brazil. Acta Biologica Venezuelica, 1994, 15(2), 11-20.

BARRELLA, W., PETRERE JÚNIOR, M., SMITH, W.S. and MONTAG, L.F.A. As relaçóes entre as matas ciliares, os rios e os peixes. In: R.R. RODRIGUES and H.F. LEITÃO FILHO, eds.
Matas ciliares: conservação e recuperação. São Paulo: EDUSP, 2000, pp. 187-200.

BEAUMORD, A.C. and PETRERE JÚNIOR, M. Comunidades de peces del rio Manso, Chapada dos Guimaraes, MT, Brasil. Acta Biologica Venezuelica, 1994, 15(2), 21-35.

BRAGA, F.M.S. Alimentação de Plagioscion squamosissimus (Osteichthyes, Sciaenidae) no reservatório de Barra Bonita, Estado de São Paulo. Iheringia: Série Zoologia, 1998, (84), 11-19.

BRITSKI, H.A. Peixes de água doce do Estado de São Paulo: sistemática. In: COMISSÃO INTERESTADUAL DA BACIA PARANÁURUGUAI. Poluição e piscicultura. São Paulo: USP, 1972, pp. 83-108.

BRITSKI, H.A., SATO, Y. and ROSA, A.B.S. Manual de identificação de peixes da Bacia do São Francisco. Brasília: Câmara dos Deputados, Coordenação de Publicações, Divisão de Piscicultura e Pesca, 1984, pp. 143.

CASTRO, R.M.C. and ARCIFA, M.F. Comunidades de peixes de reservatórios do sul do Brasil. Revista Brasileira de Biologia, 1987, 47(4), 493-500.

CONSÓRCIO NACIONAL DE ENGENHEIROS CONSULTORES - CNEC. O barramento dos rios e a fauna ictiológica. São Paulo: CNEC, 1969.

FERNANDO, C.H. Impacts of fish introductions in tropical Asia and America. Canadian Journal of Fisheries and Aquatic Sciences, 1991, 48(1), 24-32. http://dx.doi.org/10.1139/f91-301.

FOOD AND AGRICULTURE ORGANIZATION FAO. Enfoque precautorio para la pesca de captura y las introduciones de espécies: orientaciones técnicas para la pesca responsable. Rome: FAO, 1997.

GARUTTI, V. and BRITSKI, A.H. Descrição de uma espécie nova de Astyanax (Teleostei: Characidae) na Bacia do alto do Rio Paraná e consideraçóes sobre as demais espécies do gênero na bacia. Porto Alegre: Museu de Ciências da PUCRS, 2000, pp. 65-88. Comunicaçôes do Museu de Ciências da PUCRS, Série Zoologia, vol. 13.

HASSEL, J.H.V., REASH, R.J. and BROWN, H.W. Distribution of upper and middle Ohio River fishes, 1973-1985: associations with water quality and ecological variables. Journal of Freshwater Ecology, 1998, 4, 441-458. http://dx.doi.org/10.1080/0270 5060.1988.9665195.

HILSDORF, A.W. and PETRERE, M. Conservaçấo de peixes na bacia do rio Paraíba do Sul. Ciência Hoje, 2002, 30(180), 62-65.

JOHNSON, B.L., RICHARDSON, W.B. and NAIMO, T.J. Past, present and future concepts in large river ecology. BioSciense, 1995, 45(3), 134-141. http://dx.doi.org/10.2307/1312552. 
MACHADO, C.E.M., MIGUEL, J., ABREU, L.C. and MARTINS, M.A.B. A pesca no rio Tietê. São Paulo: Secretária de Agricultura, 1968, 29 p. vol. 8.

MATTHEWS, W.J. Patterns in freshwater fish ecology. London: Chapman \& Hall, 1998. http://dx.doi. org/10.1007/978-1-4615-4066-3.

MONTEIRO, F.S. Contribuição ao estudo da pesca no rio Piracicaba [Tese de Doutorado]. Piracicaba: Escola Superior de Agricultura "Luiz de Queiroz", Universidade de Sáo Paulo, 1953, 76 p.

MORETTO, E.M., MARCIANO, F.T., VELLUDO, M.R., FENERICH-VERANI, N., ESPINDOLA, E.L.G. and ROCHA, O. The recent occurrence, establishment and potential impact of Geophagus proximus (Cichlidae: Perciformes) in the Tietê River reservoirs: an Amazonian fish species introduced in the Paraná Basin (Brazil). Biodiversity and Conservation, 2008, 17(12), 3013-3025. http:// dx.doi.org/10.1007/s10531-008-9413-5.

MORING, J.R., EILER, P.D., NEGUS, M.T. and GIBBS, K.E. Ecological importance of submerged pulpwood logs in a maine reservoir. Transactions of the American Fisheries Society, 1985, 115(2), 335-342. http://dx.doi.org/10.1577/15488659(1986)115<335:EIOSPL >2.0.CO;2.

NÓBREGA, M. História do rio Tietê. São Paulo: Governo do Estado, 1978.

PELICICE, F.M., POMPEU, P.S. and AGOSTINHO, A.A. Large reservoirs as ecological barriers to downstream movements of Neotropical migratory fish. Fish and Fisheries, 2015, 16(4), 697-715. http:// dx.doi.org/10.1111/faf.12089.

ROCHA, O., ESPÍNDOLA, E.L., RIETZLER, A.C., FENERICH-VERANI, N. and VERANI, J.R. Animal invaders in São Paulo state reservoirs. Oecologia Australis, 2011, 15(3), 631-642. http:// dx.doi.org/10.4257/oeco.2011.1503.14.

ROSS, S.T. Mechanisms structuring stream fish assemblages: are there lessons from introduced species? Environmental Biology of Fishes, 1991, 30(4), 359-368. http://dx.doi.org/10.1007/BF02027979.

SAZIMA, S.P.B. As espécies de peixes oriundas da pesca artesanal num trecho do baixo rio Tietê: composição, rendimento e avaliação empirica da sustentabilidade da pesca [Dissertação de Mestrado]. Botucatu: Universidade Estadual Paulista, 2007.

SMITH, W.S. Estrutura da comunidade de peixes da bacia do rio Sorocaba - SP em diferentes situaçōes ambientais [Dissertação de Mestrado]. São Carlos: CRHEA-USP, 1999, $121 \mathrm{p}$.

SMITH, W.S. A pesca no rio Tietê. Ciência Hoje, 2006, 38(223), 20-27.

SMITH, W.S. and PETRERE JÚNIOR, M. Peixes em reservatórios: o caso de Itupararanga. Ciência Hoje, 2001, 29(170), 74-77.

SMITH, W.S., ESPÍNDOLA, E.L.G. and ROCHA, O. Environmental gradient in reservoirs of the medium and low Tietê River: limnological differences through the habitat sequence. Acta Limnologica Brasiliensia, 2014, 26(1), 7-88. http://dx.doi.org/10.1590/ S2179-975X2014000100009.

SMITH, W.S., ESPÍNDOLA, E.L.G., PEREIRA, C.C.G.F. and ROCHA, O. Impactos dos reservatórios do médio e baixo Tietê (SP) na composição das espécies de peixes e na atividade de pesca. In: UNIVERSIDADE DE SÃO PAULO - USP, ed. Recursos hidroenergéticos: usos, impactos e planejamento integrado. São Carlos: RIMa, 2002, pp. 57-72.

SMITH, W.S., ESPÍNDOLA, E.L.G., PETRERE JÚNIOR, M. and ROCHA, O. Fishing modification due to dam, pollution and introduction fish species in the Tietê River, SP, Brazil. In: C.A. BREBBIA, ed. River basin management II. Great Britain: WITPRESS, 2003a. WIT Transactions on Ecology and the Environment, vol. 60.

SMITH, W.S., PEREIRA, C.C.G.F. and ESPINDOLA, E.L.G. A importância da zona litoral para a disponibilidade de recursos alimentares à comunidade de peixes em reservatórios. In: R. HENRY, ed. Ecótonos nas interfaces dos ecossistemas aquáticos. São Carlos: RIMa, 2003b, pp. 233-248.

STAUFFER, J.C., GOLDSTEIN, R.M. and NEWMAN, R.M. Relationship of wooded riparian zones and runoff potential to fish community composition in agricultural streams. Canadian Journal of Fisheries and Aquatic Sciences, 2000, 57(2), 307-316. http:// dx.doi.org/10.1139/f99-197.

STRAŠKRABA, M. and TUNDISI, J.G. Diretrizes para o gerenciamento de lagos. In: M. STRAŠKRABA and J.G. TUNDISI, eds. Gerenciamento da qualidade da água de represas. São Carlos: Instituto Internacional de Ecologia, 2000, pp. 75-83. vol. 9.

TUNDISI, J.G. Represas do Paraná superior: limnologia e bases científicas para o gerenciamento. In: A. BOLTOVSKOY and H.L. LOPEZ, eds. Conferências de Limnologia. La Plata: Instituto de Limnología "Dr. R. A. Ringuelet", 1993, pp. 41-52.

VITULE, J.R.S., FREIRE, C.A. and SIMBERLOFF, D. Introduction of non-native freshwater fish can certainly be bad. Fish and Fisheries, 2009, 10(1), 98-108. http://dx.doi.org/10.1111/j.14672979.2008.00312.x.

WELCOMME, R.L. International introductions of inland aquatic species. Rome: FAO, 1988. FAO Fisheries Technical Papers, vol. 294.

ZARET, T.M. and PAINE, R.T. Species introduction in a tropical lake: a newly introduced piscivore can produce population changes in a wide range of trophic levels. Science, 1973, 182(4111), 449-455. http://dx.doi.org/10.1126/science.182.4111.449. PMid:17832455. 